\title{
EFFECT OF IRRIGATION SYSTEM AND PLANTS DISTRIBUTION ON GROWTH, YIELD AND WATER USE EFFICIENCY OF SOME SNAP BEAN CULTIVARS
}

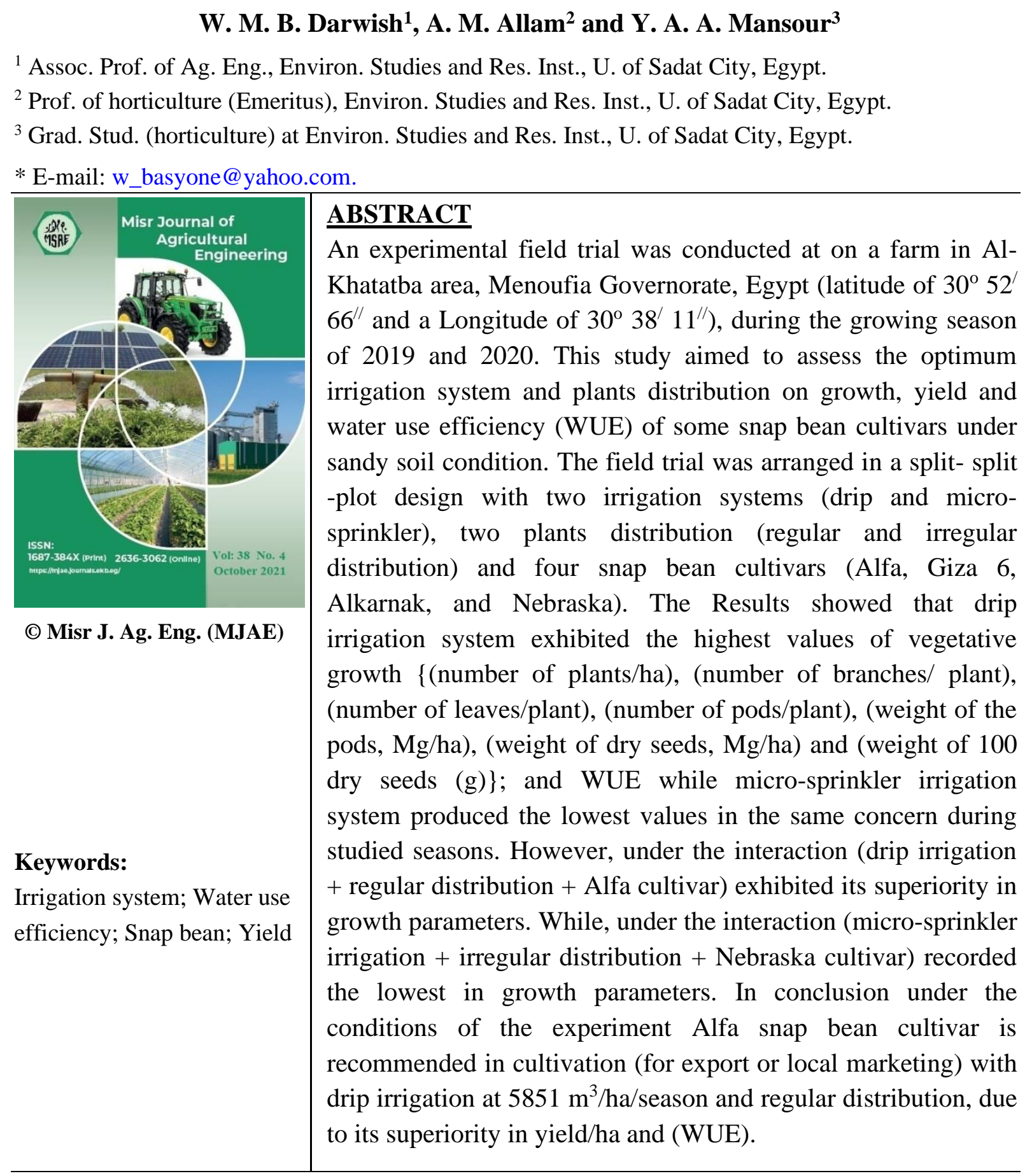

\section{INTRODUCTION}

S nap bean (Phaseolus vulgaris L.), also known as Phasolia in Egypt, is a popular vegetable crop for both local consumption and export. China is the world's leading producer of snap beans, with total production of $276134,7 \mathrm{Mg}$, Egypt is placed the sixth. It is one of Egypt's most important food crops, and it is consumed as a cooked vegetable 
in the form of dry seeds or fresh pods. Dry beans (seeds collected at full maturity), green or snap beans (completely developed pods before seed development), and green-shelled beans (immature seeds with 60-70\% seed moisture content) are the three main forms of popular bean products. Beans (Phaseolus vulgaris, L.) are one of Egypt's most significant leguminous crops for both local and international distribution. Egypt has about 28460 ha of snap bean cultivation, and 27934 ha of dry and green bean cultivation, producing about 132130 and $288630 \mathrm{Mg}$, respectively (FAO, 2019). Snap bean cultivars differ from one another in visible characteristics such as pod length and size, growth circumstances, and consumer tastes (Nielsen, 2018).

Water is becoming increasingly limited, and it is a critical component of agricultural productivity and crop development in arid and semi-arid environments. The mode of water distribution and the amount of water accessible in the soil layers at the effective root zones have an impact on crop growth and production. It's ideal to get a higher yield with the lowest quality of water feasible. Recently, the use of drip and micro-sprinkler irrigation systems has expanded dramatically around the world. The ability to boost crop yields while lowering water application, additional fertilizer, and, as a result, cultivation expenses, is one of these systems' key advantages. Drip irrigation can lead to save too much water, but only if the system is properly designed, with the right emitter spacing, flow rate, and installation depth (Rafie and El-Boraie, 2017). Drip irrigation systems, which deliver water directly to the root zone of plants, are now one of the most cost-effective ways to provide water to plants. Furthermore, drip irrigation keeps the plants over ground sections dry, making it less susceptible to bacterial or fungal infections.

A few previous studies have looked into the impact of irrigation method on crop growth and yield, and the significance of irrigation method in determining crop growth and yield potential. Tomar et al., (1999) investigated the effect of three distinct irrigation systems, (drip, micro-sprinkler, and surface irrigation), on reproductive growth and root-shoot properties of French bean plants. They found that drip irrigation produced the highest green pod output, weight and number of dried pods, number of seeds per plant, and husk weight. In addition, the drip irrigation treatment produced the most secondary and tertiary roots. With drip irrigation, the fresh shoot-root ratio was determined to be the highest. Reduced yields in micro-sprinkler irrigated snap beans compared to drip irrigated snap beans are attributed to lower oxygen concentrations in soil due to wet circumstances, which causes stomatal closure in plants, lowering transpiration rate and, as a result, crop production (Antony and Singandhupe 2004). Many studies have shown that crop yield and transpiration are substantially and linearly connected. For the snap bean, Narayanamoorthy et al. (2003) and Scholberg and Locascio (1999) found that drip irrigation resulted in higher plant height and weight than sub-irrigation. Yonts (2010) investigated the impact of irrigation method on dry bean output in response to water stress (early, mid, and late season). He concluded that the greatest difference in yield between the water stress treatments happens at the middle of the season, and it's more obvious for sprinkler irrigation than furrow irrigation. Given the importance of irrigation method on crop growth, yield, and water use, as well as the lack of understanding of these complex relationships, more research is needed to better understand the effects of water stress, irrigation methods, and their potential impacts on crop growth 
performance and yield components. The information gathered will aid attempts to close yield discrepancies in dry bean production systems across different geographic locations. Ramana Rao et al. (2017) investigated the impact of different irrigation systems on the performance of pea crop over three years-time. In their study, three irrigation systems were used (traditional flood irrigation, micro-sprinkler irrigation, and drip irrigation). The results showed that microsprinkler system irrigation system produced the highest crop yield, followed by drip and then traditional irrigation systems. Drip irrigation was proven to save more water than the microsprinkler watering technology.

Amer et al., 2002; Metin et al., 2005; Abdel-Mawgoud, 2006) found that increasing the irrigation level boosted bean growth, green pod yield, and WUE. El-Noemani et al. (2009) obtained similar results on pea plants and on Kinnow Mandarin by, Raza et al., (2020).

The overall goal of this study was to see how irrigation methods and plant distribution affected the growth, yield, and water use efficiency of several snap bean cultivars grown in a sandy soil.

\section{MATERIALS AND METHODS}

Two field experiments were conducted at a private farm in El-Khatatba located at a latitude of $30^{\circ} 52^{\prime} 66^{\prime \prime}$ and a longitude of $30^{\circ} 38^{\prime} 11^{\prime \prime}$ to assess the effect of irrigation methods (drip and micro-sprinkler) and plant distribution (regular distribution and irregular distribution as of crow legs) on growth, yield, and water use efficiency of some snap bean varieties under sandy soil conditions during the two winter growing seasons of 2019 and 2020., four snap bean cultivars (Nebraska, Giza6, Alfa, and Alkarnak) were tested for vegetative growth characteristics, yield, and its components, as well as their interaction. Under the examined region, fertilizers requirements for bean crops were added based on suggestions from the Vegetable Crop Research Institute, ARC, Ministry of Agriculture and Land Reclamation. During seed bed preparation, $500 \mathrm{~kg} / \mathrm{ha}$ of calcium super phosphate $\left(15.5 \% \mathrm{P}_{2} \mathrm{O}_{5}\right), 125 \mathrm{~kg} / \mathrm{ha}$ of ammonium sulphate $(20.5 \% \mathrm{~N})$, and $65 \mathrm{~kg} / \mathrm{ha}$ of potassium sulphate $\left(48 \% \mathrm{~K}_{2} \mathrm{O}\right)$ were applied as recommended. At the first irrigation, $125 \mathrm{~kg} / \mathrm{ha}$ of ammonium sulphate and 65 $\mathrm{kg} / \mathrm{ha}$ of potassium sulphate were added. The pipette method was used to analyses the experimental soil, the $\mathrm{pH}$ was measured in a $1 \mathrm{M}$ KCI solution, organic matter was determined using the Walkley-Black method, cation exchange capacity (CEC) was determined using ammonium acetate solution, and $\mathrm{CaCO} 3$ was determined using the calcimeter, all of which methods were cited by Black et al (1969). The contents of (N, P, K, $\mathrm{Fe}, \mathrm{Mn}, \mathrm{Zn}$, and $\mathrm{Cu}$ ) were determined according to Cottenie et al, (1982). The experimental site's soil texture was sandy, with a field capacity of $19.22 \%$, welting point of $10.06 \%$, and bulk density of $1.45 \mathrm{gm} / \mathrm{cm}^{3}$ (Jacobs et al., 1971). Tables 1 and 2 shows some physical and chemical properties of soil and water, respectively. When necessary, the approved agriculture procedures for developing snap bean plants were used. The experiment comprises 32 treatments (two methods of irrigation, two plant distribution, four cultivars and two seasons). Spilt- spilt plots design in a randomized full blocks with three replicates were used. Irrigation systems were installed in the main plots, while plant distribution and cultivars were installed in subplots and sub-sub plots, respectively. The sub-plot was $22.5 \mathrm{~m}^{2}$ in size, with two rows of $30 \mathrm{~m}$ length and $0.75 \mathrm{~m}$ width. Each variety has its own set of seeds. Nebraska, Giza 6, Alfa, and Alkarnak were planted on January $20^{\text {th }}$ and harvested on May $10^{\text {th }}$ in the first season 
2019 and planted on January $13^{\text {th }}$ and harvested on May $11^{\text {th }}$ in the second season 2020.15 $\mathrm{cm}$ apart and arranged in hills, on one side of the ridge, seeds were distributed in hills, which were subsequently thinned to one plant per hill at 30 days after sowing. As shown in Fig. 1, the entire cultivated area was divided according to the method of irrigation.

Table 1: Some physical and chemical properties of the experimental soil

\begin{tabular}{|c|c|c|c|c|c|c|c|c|c|c|c|c|c|c|c|c|c|c|c|c|c|c|}
\hline \multirow{2}{*}{ 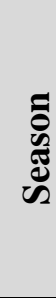 } & \multirow{2}{*}{ 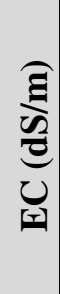 } & \multirow{2}{*}{ 竞 } & \multicolumn{4}{|c|}{$\begin{array}{c}\text { Soluble } \\
\text { cations } \\
(\mathrm{meq} / \mathrm{L})\end{array}$} & \multicolumn{3}{|c|}{$\begin{array}{c}\text { Soluble } \\
\text { anions } \\
(\mathrm{meq} / \mathrm{L})\end{array}$} & \multirow[t]{2}{*}{ «ँ } & \multicolumn{5}{|c|}{$\begin{array}{l}\text { Particle size } \\
\text { distribution }\end{array}$} & \multirow{2}{*}{$\sum_{0}^{0}$} & \multirow{2}{*}{$\sum_{\tilde{j}}^{\infty}$} & \multicolumn{5}{|c|}{$\begin{array}{c}\text { Available } \\
\text { micronutrients } \\
(\text { ppm) }\end{array}$} \\
\hline & & & $\sum^{+500}$ & $\stackrel{+}{\unlhd}$ & $\stackrel{+}{\underset{z}{z}}$ & 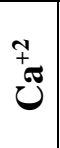 & $\frac{1}{U}$ & & 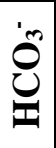 & & 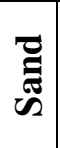 & $\Delta^{0}$ & $\begin{array}{l}0^{\circ} \\
\overrightarrow{3}\end{array}$ & $\begin{array}{l}\frac{0}{2} \\
\frac{6}{2}\end{array}$ & 总 & & & $A$ & 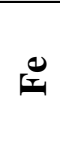 & $\overrightarrow{5}$ & 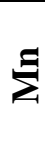 & ت \\
\hline$\stackrel{\overline{\mathcal{\sigma}}}{\overline{\mathrm{d}}}$ & $\stackrel{\infty}{0}$ & $\cong$ & $\begin{array}{l}8 \\
i\end{array}$ & is & 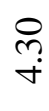 & 8 & ๑ & & & $\stackrel{\nabla}{\circ}$ & or & $\approx$ & $\stackrel{\infty}{-}$ & $\stackrel{\nabla}{\sim}$ & 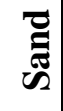 & $\begin{array}{l}\infty \\
\infty \\
0\end{array}$ & $\begin{array}{l}\infty \\
\dot{m}\end{array}$ & - & $\stackrel{n}{n}$ & $\begin{array}{l}0 \\
? \\
0\end{array}$ & $\hat{0}$ & 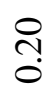 \\
\hline ฮั่ & $\hat{o}$ & $m$ & 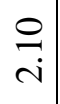 & & & 으 & 8 & & & ? & $n$ & 8 & $\infty$ & 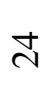 & 节 & $\begin{array}{l}0 \\
\infty \\
0\end{array}$ & $\vec{m}$ & 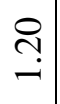 & กิ & $\stackrel{n}{0}$ & 0 & 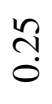 \\
\hline
\end{tabular}

(*) Saturation percentage

Table 2: Chemical analysis of irrigation water during the two experimental seasons of 2019 and 2020

\begin{tabular}{|c|c|c|c|c|c|c|c|c|c|c|c|}
\hline \multirow{2}{*}{ Season } & \multirow{2}{*}{$\mathbf{p H}$} & \multirow{2}{*}{$\begin{array}{c}\text { EC } \\
(\mathbf{d S} / \mathbf{m})\end{array}$} & \multicolumn{4}{|c|}{ Cations (meq/l) } & \multicolumn{4}{|c|}{ Anions (meq/l) } & \multirow[b]{2}{*}{ SAR } \\
\hline & & & $\mathrm{Ca}^{++}$ & $\mathbf{M g}^{++}$ & $\mathbf{N a}^{++}$ & $\mathbf{K}^{+}$ & $\mathrm{CO}_{3}^{-}$ & $\mathrm{HCO}_{3}^{-}$ & $\mathrm{Cl}^{-}$ & $\mathrm{SO}_{4}^{-2}$ & \\
\hline 2019 & 7.13 & 1.18 & 5.40 & 0.76 & 3.15 & 2.51 & 0.0 & 3.69 & 3.34 & 4.77 & 0.95 \\
\hline 2020 & 7.20 & 1.20 & 5.45 & 0.76 & 3.25 & 2.54 & 0.0 & 3.77 & 3.40 & 4.83 & 1.24 \\
\hline
\end{tabular}

Data from the weather station:

In 2019 and 2020, the Central Meteorological Lab, Ministry of Agriculture, Cairo (ElKhatatba city) recorded and measured monthly maximum, minimum, average air temperatures, wind speed, rainfall, and average daily evapotranspiration (ETo) at the experimental site as listed in Table 3:

Table 3: Monthly maximum, minimum, average temperature, wind speed, rainfall and average daily evapotranspiration (ET $)$ for the experimental site during 2019 and 2020

\begin{tabular}{|c|c|c|c|c|c|c|c|c|c|c|c|c|}
\hline \multirow{2}{*}{$\begin{array}{l}\text { Month } \\
\text { Season }\end{array}$} & \multicolumn{2}{|c|}{$\mathbf{T}_{\max (\mathbf{c o})}$} & \multicolumn{2}{|c|}{$\mathbf{T}_{\min (c o)}$} & \multicolumn{2}{|c|}{$\mathbf{T}_{\text {mean }(\mathbf{c o})}$} & \multicolumn{2}{|c|}{$\begin{array}{c}\text { Average } \\
\text { wind speed } \\
\text { Ws }(\mathbf{m} / \mathbf{s})\end{array}$} & \multicolumn{2}{|c|}{$\begin{array}{c}\text { Average } \\
\text { rainfall } \\
\left(\mathbf{m m} / \mathbf{m}^{2}\right)\end{array}$} & \multicolumn{2}{|c|}{$\begin{array}{c}\mathbf{E T}_{\mathbf{o}} \\
(\mathbf{m m} / \mathbf{d a y})\end{array}$} \\
\hline & 2019 & 2020 & 2019 & 2020 & 2019 & 2020 & 2019 & 2020 & 2019 & 2020 & 2019 & 2020 \\
\hline Jan -Feb & 22.66 & 20.25 & 6.73 & 6.04 & 13.03 & 12.48 & 1.10 & 0.03 & 0.21 & 0.03 & 3.20 & 2.90 \\
\hline Feb -Mar & 22.29 & 20.9 & 8.81 & 7.63 & 15.13 & 13.88 & 1.53 & 0.16 & 0.24 & 0.16 & 4.10 & 4.00 \\
\hline Mar-Apr & 25.71 & 23.9 & 10.04 & 9.36 & 17.45 & 16.32 & 1.51 & 0.02 & 0.02 & 0.02 & 5.80 & 5.50 \\
\hline Apr-May & 30.31 & 28.65 & 13.82 & 12.14 & 21.78 & 19.87 & 1.85 & 0.09 & 0.08 & 0.09 & 7.70 & 6.70 \\
\hline
\end{tabular}




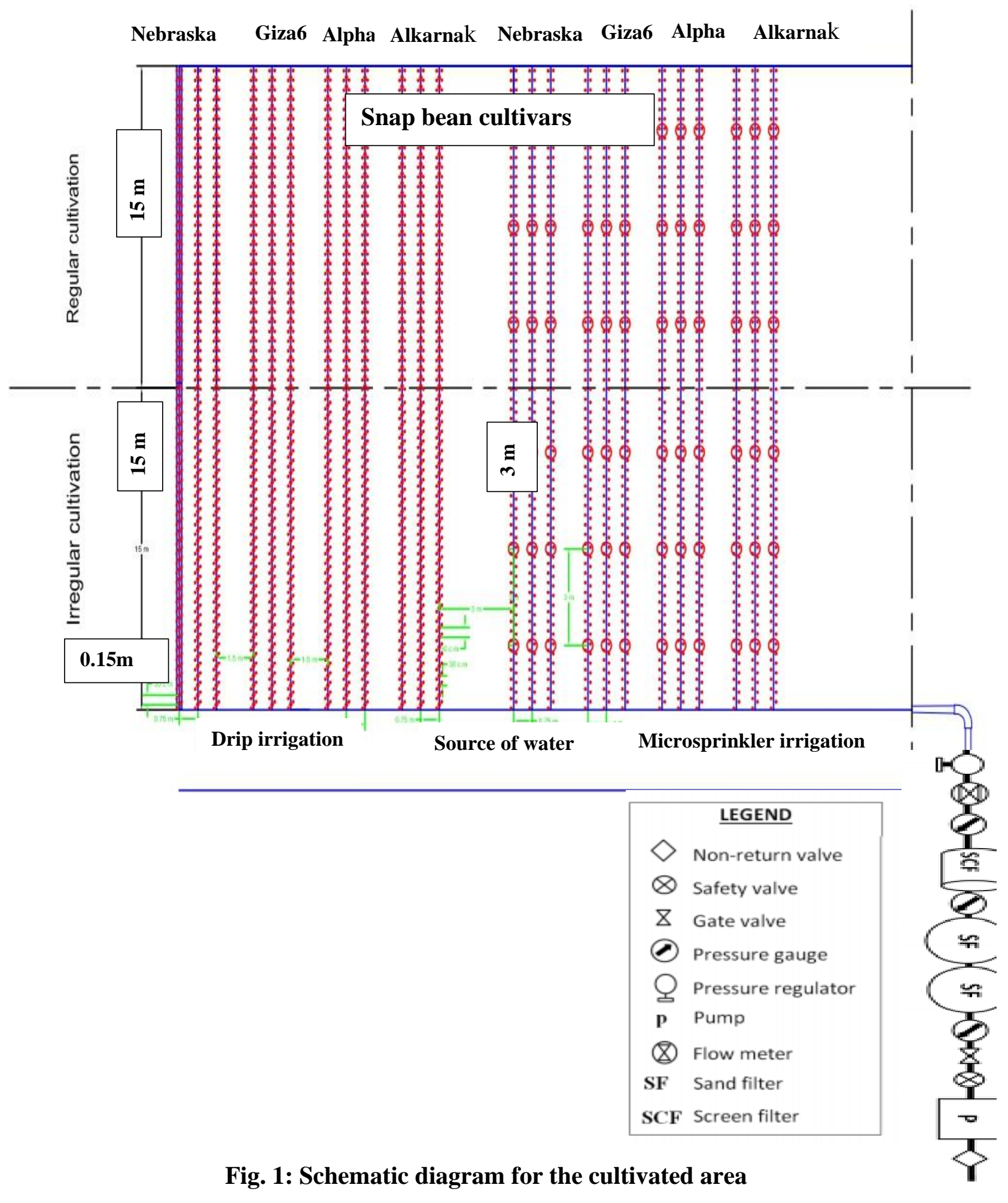

\section{Water required for irrigation:}

Using the CROPWAT Package, the FAO Penman-Monteith method (Allen et al., 1998) was utilized to determine the reference evapotranspiration $\mathrm{ET}_{\mathrm{o}}$. $\mathrm{ET}_{\mathrm{o}}$ was used to calculate crop water requirements $\left(\mathrm{ET}_{\mathrm{c}}\right)$ across the growing season using the following equation:

$$
\mathrm{ET}_{\mathrm{c}}=\mathrm{K}_{\mathrm{c} .} \mathrm{ET}_{\mathrm{o}}
$$


Where: $\mathrm{ET}_{\mathrm{c}}$ is the crop water requirements, $\mathrm{K}_{\mathrm{c}}$ is the crop coefficient and $\mathrm{ET}_{\mathrm{o}}$ is the reference evapotranspiration. Since there was no rainfall during the experimental period, net irrigation requirement was taken to be equal to $\mathrm{ET}_{\mathrm{c}}$.

During both seasons of 2019 and 2020, the total amounts of irrigation water applied (from sowing to harvesting) were 5851 and $6660 \mathrm{~m}^{3} /$ ha for drip and micro-sprinkler irrigation systems, respectively. Based on crop growth phases and weather data, the amount of water needed for each month was calculated.

\section{Irrigation Methods:}

To irrigate bean plants, two irrigation methods were chosen. The first is a drip irrigation system with GR of $4 \mathrm{~L} / \mathrm{h}$ emitters spaced $30 \mathrm{~cm}$ apart. At a distance of $75 \mathrm{~cm}$, polyethylene lateral lines with a diameter of $16 \mathrm{~mm}$ were employed. Micro-sprinkler irrigation is the second system with the same laterals, but they were $(8 \mathrm{~L} / \mathrm{h}$ each with a $3 \mathrm{~m}$ wet diameter).

\section{Distribution uniformity of drip and micro-sprinkler irrigation systems}

Burt et al. (1997) addressed various definitions of irrigation system efficiency and distribution uniformity. Because irrigation system efficiency is dependent on management and design, it is difficult to assess. It can be measured with crop lysimeters or continuous soil moisture measurements. For micro-sprinkler and drip irrigation systems, the low quarter distribution uniformity is frequently employed to assess the performance of the system.

$$
\mathrm{DU}_{\mathrm{lq}}=\frac{V_{\mathrm{lq}}}{V}
$$

Where: $\mathrm{DU}_{\mathrm{lq}}$ is the low quarter distribution uniformity,

$\mathrm{V}_{\mathrm{lq}}$ is the average volume caught in the lowest $25 \%$ of volumes collected, and $\mathrm{V}$ is the overall average of volumes collected.

The emitters and micro-sprinklers utilized in this study for the field investigation were calibrated early in the winter of each growing season. Collecting catch cans were placed up radially from the emitter $0.5 \mathrm{~m}$ apart and up to $3 \mathrm{~m}$ from the plants to evaluate microsprinklers. The micro-sprinklers discharge was tested for 30 minutes. For drippers, discharge was monitored using a graded glass at each emitter around the plant for one minute. Under $100 \mathrm{kPa}$, the uniformity coefficients for drip and micro-sprinklers irrigation were about $92 \%$ and $80 \%$, respectively. According to James (1988) and Bilalis et al., (2009) the water use efficiency (WUE) of snap bean in each treatment was calculated using the total fresh pod weight (marketable and unmarketable yield) as follows:

$$
\text { WUE }=\frac{\text { Total weight of fresh pod }}{\text { Total water applied }}
$$

Where: WUE is the water use efficiency $\left(\mathrm{kg} / \mathrm{m}^{3}\right)$, total weight of fresh pod yield $(\mathrm{kg} / \mathrm{fed})$ and the total water applied $\left(\mathrm{m}^{3} / \mathrm{ha}\right)$

\section{Yield and its components:}

Each plot's dry pods were collected when reached maturity, counted, and weighed, and the following parameters were calculated:

1- Dry seeds (Mg/ha).

2- Weight of 100 seeds

3- Total seeds yield (Mg/ha). 
Weight of dry seeds: Pods were randomly collected from the bottom, mid, and upper parts of the plants during harvesting time from the same three $\mathrm{m}^{2}$ randomly selected and tagged plants, and these pods were trashed individually. Numbers of seed per pod were counted carefully from each plot and measured by a sensitive balance at $12.5 \%$ moisture content and expressed as $\mathrm{Mg} / \mathrm{ha}$.

100 Seed weight: A sample of threshed seeds from each plot was counted using an electronic seed counter and measured by sensitive balance at $12.5 \%$ moisture content.

Yield: Bean yields were discarded and measured from the net plot area of the harvestable row (without border influence in the middle rows) and expressed as $\mathrm{Mg} / \mathrm{ha}$. A computerized moisture tester was used to regulate the bean yield to $12.5 \%$ moisture.

\section{Morphological characters:}

Number of pods per plant, Number of plants $/ \mathrm{m}^{2}$, Number of leaves/plants and Number of branches/plants

Number of pods per plant: These were taken from the same three randomly selected tagged pants at the end of harvest in each plot and the number of pods were counted and recorded carefully.

Number of plants $/ \mathbf{m}^{2}$ : These were taken from the same three randomly selected tagged pants at the end of harvest in each plot that equal $1 \mathrm{~m}^{2}$ and the number of plants were counted and recorded carefully.

Number of leaves/plant: These were taken from the same three randomly selected tagged pants at the end of harvest in each plant and the number of leaves were counted and recorded carefully.

Number of branches/plant: These were taken from the same three randomly selected tagged pants at the end of harvest in each plant and the number of branches were counted and recorded carefully.

\section{Statistical analysis:}

All recorded data were subjected to ANOVA to identify significant treatments and/or interaction effects by ' $F$ test' using the SPSS program (SPSS Systems for Windows, version 20). Mean separation between the significant treatments was calculated by least significant difference (L.S.D).

\section{RESULTS AND DISCUSSION}

Main effect of irrigation systems, plant distribution and cultivars on some vegetative growth characteristics of snap bean in both seasons

\section{Effect of irrigation systems:}

Data in Tables 4 and 5 shows the effect of irrigation systems; (drip and micro-sprinkler) on vegetative growth of snap bean plants. In both studied seasons, data showed that the higher values for (number of plants/ha), (number of branches/plant), (number of leaves/plant), (number of pods/plant), (weight of the pods $\mathrm{Mg} / \mathrm{ha}$ ), (weight of dry seeds $\mathrm{Mg} / \mathrm{ha}$ ) and (weight of 100 dry seeds, g) were found with drip irrigation as compared with micro-sprinkler irrigation but without any significant differences except for the number of pods/plant during both seasons, number of leaves/plant during season 2019 only and weight of dry seeds 
(Mg/ha) during season 2020 only were highly significant difference for drip irrigation as compared with micro-sprinkler irrigation. Generally, drip irrigation system was, more suitable for obtaining higher growth parameters in the studied seasons compared with micro-sprinkler. The obtained results are in agreement with these obtained by Tomar et., al. (1999), Kassem (2000), Haikel and Farid (2001), Narayanamoorthy et al, (2003), Kassab et al. (2005), and Yonts (2010) who found that drip irrigation is more advantageous than micro-sprinkler.

\section{Effect of plant distribution:}

Data found in Tables 4 and 5 present the effect of plant distribution (regular distribution and irregular distribution as crow legs) on vegetative growth of snap bean in 2019 and 2020. It is clear from the Tables 4 and 5 that a quite similar trend was obtained in both experimental seasons regarding the effect of irrigation on the studied growth parameters. In both seasons, (number of plants/ha), (number of branches/plant), (number of leaves/plant), (number of pods/plant), (weight of the pods, $\mathrm{Mg} / \mathrm{ha}$ ), (weight of dry seeds, $\mathrm{Mg} / \mathrm{ha}$ ) and (weight of 100 dry seeds, g) were increased without significant differences by regular distribution. Moreover, the number of leaves/plant during studied seasons and weight of 100 dry seeds (g) for season 2019 only were highly significantly difference by regular distribution as compared with irregular distribution. Many researchers, including Pawar et al. (2007), Abd El-Latif et al. (2009), Moniruzzaman et al. (2009), and Kazemi et al. (2012), El-Seifi et al. (2014) agree with these results.

\section{Effect of cultivars:}

Growth parameters of snap bean cultivars in the two experimental seasons of 2019 and 2020 are presented in Tables 4 and 5. Data showed that growth number of plants/ha during studied seasons, (number of branches/ plant) during season of 2020 only, (number of pods/plant) during season of 2019 only, (weight of dry seeds $\mathrm{Mg} / \mathrm{ha}$ ) during season of 2020 only and (weight of 100 dry seeds ( $\mathrm{g}$ ) during season 2019 only were significantly affected by snap bean cultivars. Moreover, regarding the number of leaves/plant and weight of pods $(\mathrm{Mg} / \mathrm{ha})$, there were no significant differences between the four varieties in the two growing seasons. It is worthy to mention that Alfa and Giza 6 cultivars exhibited its superiority in all aforementioned growth characteristics. Contrarily, in both growing seasons, Nebraska cultivar showed its inferiority against other cultivars in the same regard. The different behavior of cultivars observed in the studied characters might reflect the differential expressivity of certain genes during autogenetic processes. These results are in agreement with those obtained by Nassar (1986) on snap bean, Abou El-Hassan et al. (1993) on bean and Amer et al. (2002) on bean.

Effects of interaction between irrigation system, plant distribution and cultivars of snap bean during studied seasons

Effect of interaction among irrigation systems, plant distribution and cultivars of snap bean on vegetative growth characteristics is exhibited in Tables 6 and 7. Significant differences due to interaction were attained in all growth parameters in both experimental seasons. It is worthy to mention that in most cases the greatest values of the significantly affected characters in the two seasons were recorded by Alfa and Giza 6 variety with the treatment of regular distribution and drip irrigation system, these outcomes matched those predicted by Nassar (1986), Kazemi et al. (2012) and El-Seifi et al. (2014). 
Table 4: Main effect of irrigation systems, plant distribution and cultivars on some vegetative growth characteristics of snap bean in both seasons

\begin{tabular}{|c|c|c|c|c|c|c|c|c|c|}
\hline \multirow{3}{*}{\multicolumn{2}{|c|}{$\begin{array}{c}\text { Seasons } \\
\text { Characteristics } \\
\text { Treatments }\end{array}$}} & \multicolumn{4}{|c|}{2019} & \multicolumn{4}{|c|}{2020} \\
\hline & & \multirow{3}{*}{$\begin{array}{c}\begin{array}{c}\text { No. of } \\
\text { plants /ha }\end{array} \\
195985^{\text {a }}\end{array}$} & \multirow{3}{*}{$\begin{array}{c}\begin{array}{c}\text { No. of } \\
\text { branches/ } \\
\text { plant }\end{array} \\
4.958^{\text {a }} \\
\end{array}$} & \multirow{3}{*}{$\begin{array}{c}\begin{array}{c}\text { No. of } \\
\text { leaves/plant }\end{array} \\
47.21^{\mathrm{a}}\end{array}$} & \multirow{3}{*}{$\begin{array}{c}\begin{array}{c}\text { No. of } \\
\text { pods/plant }\end{array} \\
8.21^{\text {a }} \\
\end{array}$} & \multirow{3}{*}{$\begin{array}{c}\begin{array}{c}\text { No. of } \\
\text { plants /ha }\end{array} \\
201115^{\text {a }}\end{array}$} & \multirow{3}{*}{$\begin{array}{c}\begin{array}{c}\text { No. of } \\
\text { branches/ } \\
\text { plant }\end{array} \\
5^{\mathrm{a}}\end{array}$} & \multirow{3}{*}{$\begin{array}{c}\begin{array}{c}\text { No. of } \\
\text { leaves/plant }\end{array} \\
43.13^{\text {a }}\end{array}$} & \multirow{3}{*}{$\begin{array}{c}\begin{array}{c}\text { No. of } \\
\text { pods/plant }\end{array} \\
9.17^{\text {a }}\end{array}$} \\
\hline & & & & & & & & & \\
\hline \multirow{2}{*}{ 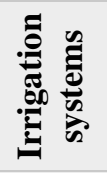 } & Drip & & & & & & & & \\
\hline & $\begin{array}{c}\text { Micro } \\
\text { sprinkler }\end{array}$ & $183635^{a}$ & $4.667^{\mathrm{a}}$ & $35.13^{b}$ & $7.38^{b}$ & $178885^{a}$ & $4.542^{\mathrm{a}}$ & $35.75^{\mathrm{a}}$ & $7.63^{b}$ \\
\hline \multicolumn{2}{|c|}{ L.S.D.at 5\% } & NS & NS & * & * & NS & NS & NS & * \\
\hline \multirow{2}{*}{ 产 } & Regularly & $203870^{a}$ & $5.04^{\mathrm{a}}$ & $42.13^{\mathrm{a}}$ & $8.08^{a}$ & $202635^{a}$ & $4.88^{\mathrm{a}}$ & $45.21^{\mathrm{a}}$ & $8.54^{\mathrm{a}}$ \\
\hline & Irregular & $175750^{a}$ & $4.58^{\mathrm{a}}$ & $36.75^{b}$ & $7.50^{\mathrm{a}}$ & $177365^{a}$ & $4.67^{\mathrm{a}}$ & $37.13^{\mathrm{b}}$ & $8.25^{\mathrm{a}}$ \\
\hline \multicolumn{2}{|c|}{ L.S.D.at 5\% } & NS & NS & $*$ & NS & NS & NS & $*$ & NS \\
\hline \multirow{4}{*}{ 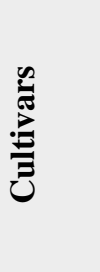 } & Alfa & $225625^{a}$ & $5.08^{\mathrm{a}}$ & $42.58^{\mathrm{a}}$ & $8.83^{\mathrm{a}}$ & $225625^{a}$ & $5.08^{\mathrm{a}}$ & $42.92^{\mathrm{a}}$ & $9.08^{\mathrm{a}}$ \\
\hline & Giza 6 & $190760^{b}$ & $5.08^{\mathrm{a}}$ & $41^{\mathrm{a}}$ & $8.25^{\mathrm{ab}}$ & $190760^{\mathrm{b}}$ & $4.75^{\mathrm{ab}}$ & $40.5^{\mathrm{a}}$ & $8.75^{\mathrm{a}}$ \\
\hline & Alkarnak & $185250^{b}$ & $4.83^{\mathrm{a}}$ & $40.58^{a}$ & $7.42^{b c}$ & $189240^{b}$ & $4.67^{\mathrm{ab}}$ & $38.33^{\mathrm{a}}$ & $8.08^{\mathrm{a}}$ \\
\hline & Nebraska & $157510^{c}$ & $4.25^{\mathrm{a}}$ & $40.5^{\mathrm{a}}$ & $6.67^{\mathrm{c}}$ & $154375^{c}$ & $4.58^{\mathrm{b}}$ & $36^{a}$ & $7.67^{\mathrm{a}}$ \\
\hline \multicolumn{2}{|c|}{ L.S.D.at5\% } & * & NS & NS & * & * & * & NS & NS \\
\hline
\end{tabular}

Means followed by the same letter are not significantly different from one another based on Duncan's multiple range test at a $\mathrm{p} \leq 0.05$ significance level. NS indicate non-significant, ${ }^{*}$ Significant at $\mathrm{P} \leq 0.05$.

Table 5: Main effect of irrigation systems, plant distribution and cultivars on some vegetative growth characteristics of snap bean in both seasons

\begin{tabular}{|c|c|c|c|c|c|c|c|}
\hline \multicolumn{2}{|c|}{ Seasons } & \multicolumn{3}{|c|}{2019} & \multicolumn{3}{|c|}{2020} \\
\hline \multirow{2}{*}{\multicolumn{2}{|c|}{$\begin{array}{c}\text { Characteristics } \\
\text { Treatments }\end{array}$}} & Weight of the & Weight of & Weight of 100 & Weight of the & Weight of dry & Weight of 100 \\
\hline & & $\left(\mathrm{Mg} . \mathrm{ha}^{-1}\right)$ & $\left(\mathrm{Mg} \mathrm{ha}^{-1}\right)$ & (g) & (Mg/ha) & (Mg/ha) & (g) \\
\hline \multirow{2}{*}{ 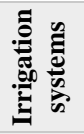 } & Drip & $6.14^{\mathrm{a}}$ & $1.47^{\mathrm{a}}$ & $46.29^{a}$ & $8^{a}$ & $1.90^{\mathrm{a}}$ & $48.63^{a}$ \\
\hline & Micro sprinkler & $5.33^{\mathrm{a}}$ & $1.39^{\mathrm{a}}$ & $45.46^{\mathrm{a}}$ & $6.30^{\mathrm{a}}$ & $1.48^{b}$ & $46.29^{a}$ \\
\hline \multicolumn{2}{|c|}{ L.S.D.at 5\% } & NS & NS & NS & NS & $*$ & NS \\
\hline \multirow{2}{*}{ 竞 } & Regularly & $5.84^{\mathrm{a}}$ & $1.45^{\mathrm{a}}$ & $47.42^{\mathrm{a}}$ & $7.17^{\mathrm{a}}$ & $1.79^{\mathrm{a}}$ & $48.54^{\mathrm{a}}$ \\
\hline & Irregular & $5.63^{\mathrm{a}}$ & $1.41^{\mathrm{a}}$ & $44.33^{b}$ & $7.13^{\mathrm{a}}$ & $1.59^{\mathrm{a}}$ & $46.38^{a}$ \\
\hline \multicolumn{2}{|c|}{ L.S.D.at $5 \%$} & NS & NS & $*$ & NS & NS & NS \\
\hline \multirow{4}{*}{ 营 } & Alfa & $6.01^{\mathrm{a}}$ & $1.46^{\mathrm{a}}$ & $47.25^{\mathrm{a}}$ & $7.45^{\mathrm{a}}$ & $1.86^{\mathrm{a}}$ & $48.67^{\mathrm{a}}$ \\
\hline & Giza 6 & $5.70^{\mathrm{a}}$ & $1.46^{\mathrm{a}}$ & $46.67^{\mathrm{a}}$ & $7.36^{\mathrm{a}}$ & $1.74^{\mathrm{ab}}$ & $48^{a}$ \\
\hline & Alkarnak & $5.69^{\mathrm{a}}$ & $1.43^{\mathrm{a}}$ & $46.42^{\mathrm{a}}$ & $6.97^{\mathrm{a}}$ & $1.61^{\mathrm{ab}}$ & $46.5^{\mathrm{a}}$ \\
\hline & Nebraska & $5.53^{\mathrm{a}}$ & $1.37^{\mathrm{a}}$ & $43.17^{\mathrm{b}}$ & $6.81^{\mathrm{a}}$ & $1.56^{\mathrm{b}}$ & $46.58^{\mathrm{a}}$ \\
\hline \multicolumn{2}{|c|}{ L.S.D.at5\% } & NS & NS & $*$ & NS & $*$ & NS \\
\hline
\end{tabular}

Means followed by the same letter are not significantly different from one another based on Duncan's multiple range test at a $\mathrm{p} \leq 0.05$ significance level. NS indicate non-significant, *Significant at $\mathrm{P} \leq 0.05$. 


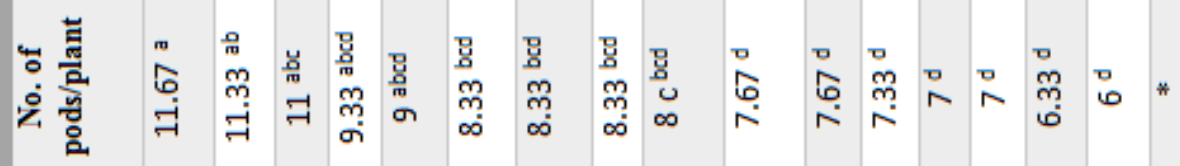

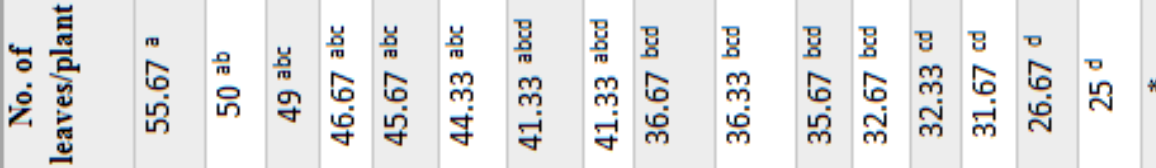

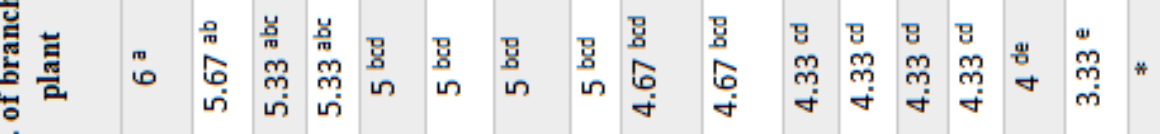
安

望 总

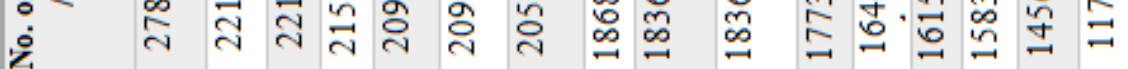

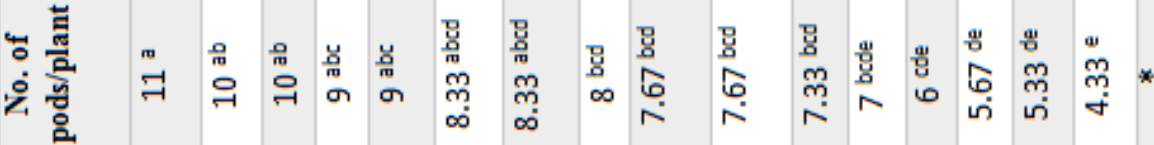

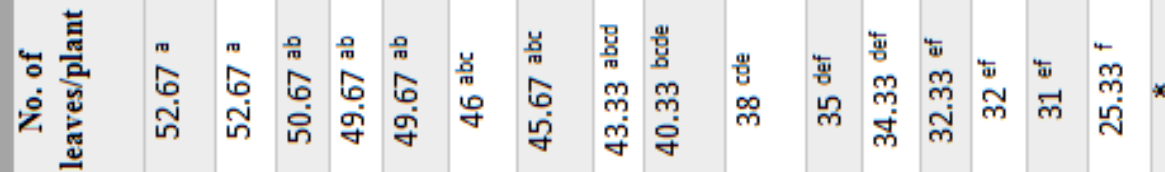

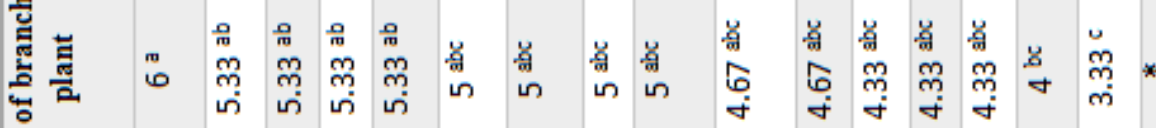
:

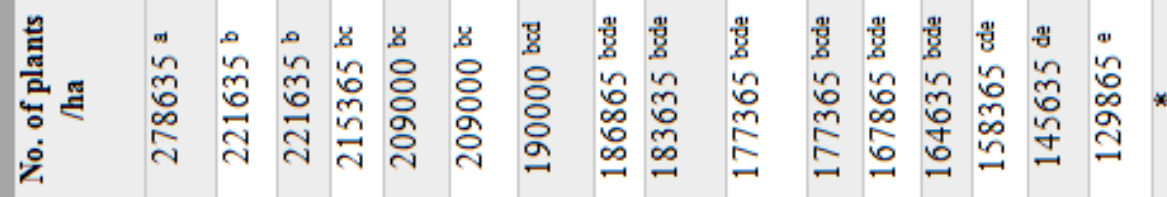

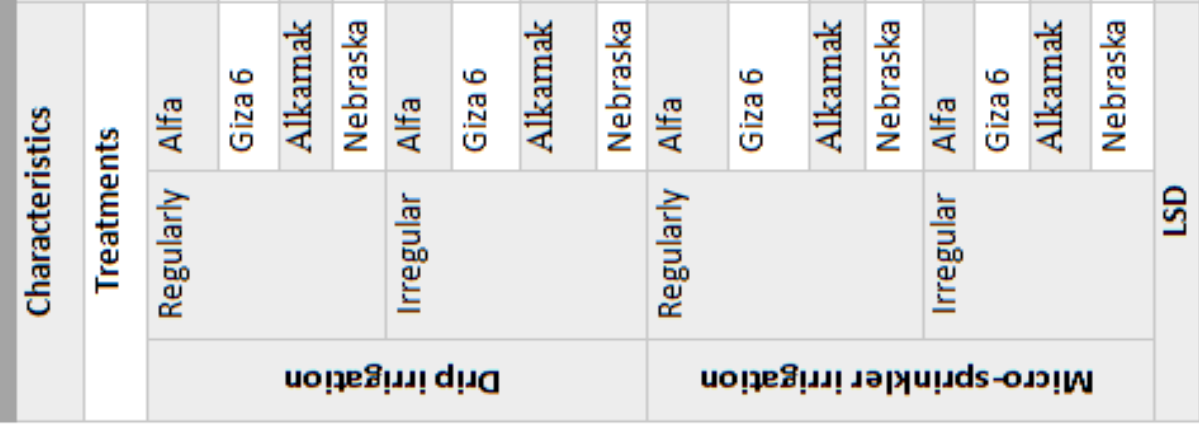

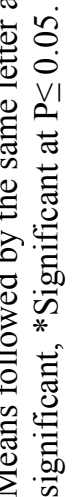




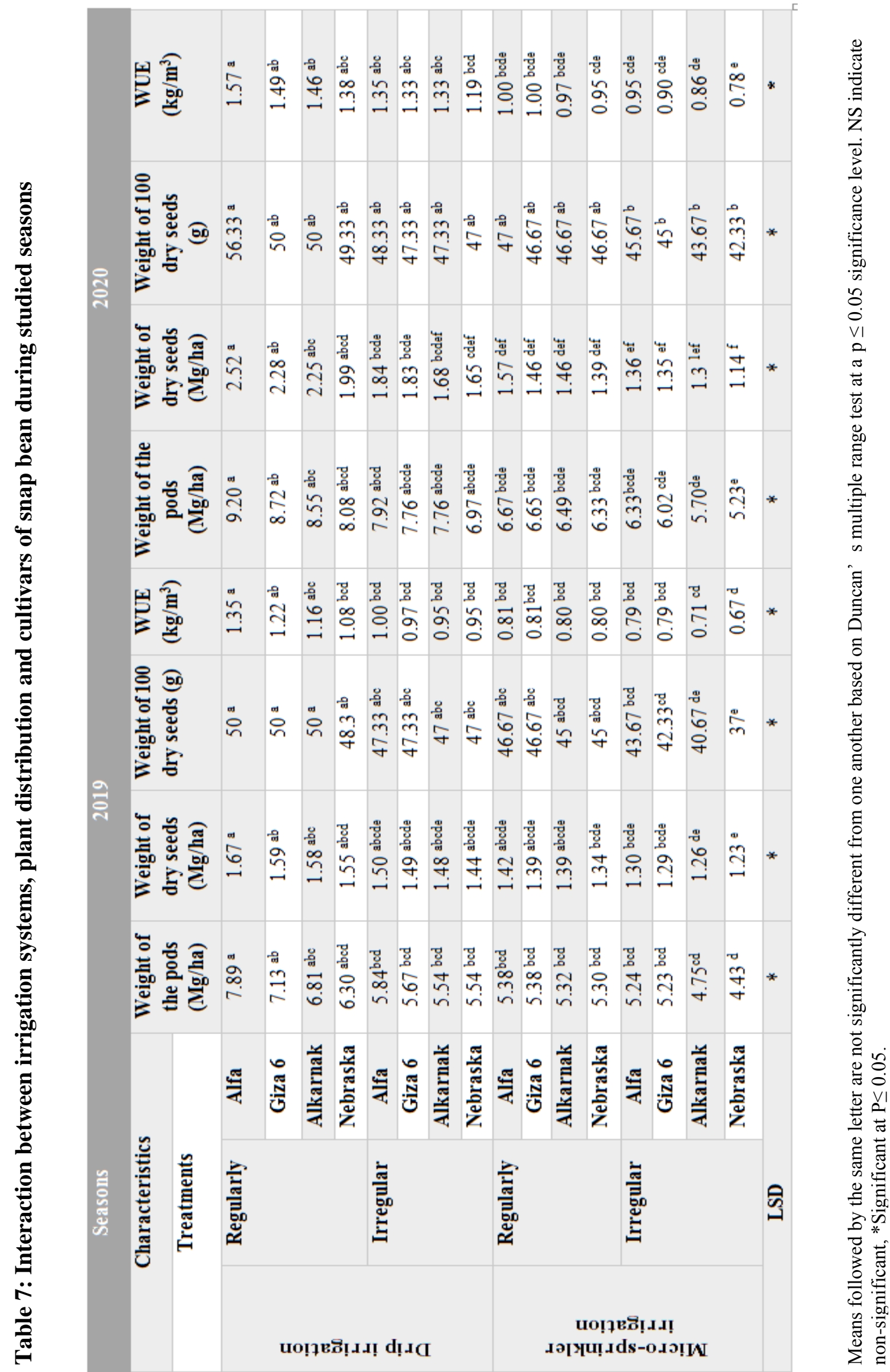




\section{Water use efficiency:}

Seasonal water used by snap bean varied from $5851 \mathrm{~m}^{3} / \mathrm{ha}$ for drip irrigation to $6660 \mathrm{~m}^{3} / \mathrm{ha}$ for micro-sprinkler irrigation in the studied seasons 2019 and 2020.The different values of Seasonal water used by snap bean referred to the higher efficiency of drip irrigation compared to micro-sprinkler irrigation. The highest $\mathrm{WUE}_{\text {(weight of the pods) }}$ of $1.57 \mathrm{~kg} / \mathrm{m}^{3}$ was obtained with the treatment (drip irrigation + regular distribution and Alfa cultivar) in the 2020 season and the minimum $\mathrm{WUE}_{\text {(weight of the pods) }}$ of $0.67 \mathrm{~kg} / \mathrm{m}^{3}$ was observed with the treatment (microsprinkler irrigation + irregular distribution and Nebraska cultivar) in the 2019 season. Broadly, WUE values decreased with using micro-sprinkler irrigation system because this system was less efficient than the drip irrigation system as a result of consuming more water. Erdem et al., 2006: Unlu et al., 2006; El-Hendawy et al., 2008; El-Noemani et al., 2010; El-Noemani et al., 2015; Yonts et al., 2018; Abuarab et al., 2020; Raza et al.,2020) had the findings. Improved yields under drip irrigation could arise from keeping soil moisture at an optimal level through more frequent water applications, as concluded by Phene (1991). Similarly, Yin et al. (2011) reported that drip irrigation system consumed only $21 \%$ to $29 \%$ of irrigation water compared with micro sprinkler irrigation system, and WUE was improved by $167 \%$ to $234 \%$ with drip irrigation system compared with micro sprinkler irrigation system.

\section{CONCLUSIONS}

The aim of this study was to investigate the effect of irrigation system and plants distribution on growth, yield and water use efficiency of some snap bean varieties under sandy soil condition. It could be concluded that under the conditions of this experiment, drip irrigation system was the best system to be used.

- The highest value of the number of plants/ha was 278635 plants /ha in the growing season of 2019 and 2020 under the interaction (drip irrigation + regular distribution and Alfa cultivar) while the lowest values were 129865 and 117135 plants/ha in the growing season of 2019 and 2020, respectively under the interaction (micro-sprinkler irrigation + irregular distribution and Nebraska cultivar).

- The highest value of the number of number of leaves/plant was 55.67 leaves/plant in the studied seasons under interaction (drip irrigation + regular distribution and Alfa cultivar) when the lowest value was 25 leaves/plant in the studied season 2020 under interaction (micro-sprinkler irrigation + irregular distribution and Nebraska cultivar).

- Weight of the pods $(\mathrm{Mg} / \mathrm{ha})$ recorded the highest value $(9.2 \mathrm{Mg} / \mathrm{ha})$ in the studied season 2020 under interaction (drip irrigation + regular distribution and Alfa cultivar), when the lowest value $(4.43 \mathrm{Mg} / \mathrm{ha}$ ) in the studied season2019 under interaction (micro-sprinkler irrigation + irregular distribution and Nebraska cultivar).

- Weight of dry seeds $(\mathrm{Mg} / \mathrm{ha})$ recorded the highest value $(2.52 \mathrm{Mg} / \mathrm{ha})$ in the studied season 2020 under interaction (drip irrigation + regular distribution and Alfa cultivar), when the lowest value $(1.14 \mathrm{Mg} / \mathrm{ha})$ in the studied season2020 under interaction (micro-sprinkler irrigation + irregular distribution and Nebraska cultivar).

- Weight of 100 dry seeds (g) recorded the highest value (56.33 g) in the studied season 2020 under interaction (drip irrigation + regular distribution and Alfa cultivar), when the lowest 
value (37 g) in the studied season 2019 under interaction (micro-sprinkler irrigation + irregular distribution and Nebraska cultivar).

- The highest WUE (weight of the pods) $1.57 \mathrm{~kg} / \mathrm{m}^{3}$ was obtained under (drip irrigation + regular distribution and Alfa cultivar) in the second season 2020 and the minimum WUE (weight of the pods) $0.67 \mathrm{~kg} / \mathrm{m}^{3}$ was observed under (micro-sprinkler irrigation + irregular distribution and Nebraska cultivar) in the first season 2019.

\section{REFERENCES}

Abd El-Latif, A.A., Hedawy, S.H., and Barsom, M.S. (2009). Effect of planting date and plant densities on cowpea productivity growing at new valley. Manosura J. Agric. 34 (12), 11247-11258.

Abdel-Mawgoud, A.M.R. (2006). Growth, yield and quality of green bean (Phaseolus vulgaris L.) in response to irrigation and compost applications. Journal of Applied sciences Research, 2(7), 443-450.

Abuarab, M.E., Hafez, S.M., Shahein, M.M., Hassan, A.M., El-Sawy, M.B., El-Mogy, M.M., and Abdeldaym, E. (2020). Irrigation scheduling for green beans grown in clay loam soil under a drip irrigation system. Water SA 46(4) 573-582.

Abou El-Hassan, E.A., Shahien, A.H.M. and Youssef, M.S. (1993). Effect of nitrogen and phosphorus fertilizer on some cultivars of bean plants. I. Morphological characters, yield and pod characteristics. Minia, First Conf. Hort. Crops, 19-21.

Allen, R. G., Pereira, L. S., Raes, D., and Smith, M. (1998). Crop Evapotranspiration Guidelines for Computing Crop Water Requirements. FAO Irrigation. And Drain. Paper 56. United Nations, Rome, Italy, pp. $30-42$.

Amer, A.H., El - Desuki, M., Sawan, Omaima, M., and Ibrahim, A.M. (2002). Patentiality of some snapbean (Phaseolus vulgaris L.) varieties under different irrigation levels at Shark El - Owinat Region. Egypt J. Appl. Sci., 17(1), 327-34.

Antony, E., and Singandhupe, R. B. (2004). Impact of drip and surface irrigation on growth, yield and WUE of capsicum (Capsicum annum L.). Agricultural Water Management, 65(2), 121- 132 .

Black, C. A. (1969). Methods of soil analysis. American Society of Agronomy. Inc., Publisher Madison, Wisconsin, USA.

Bilalis, D., Karkanis, A., Efthimiadou, A., Konstantas, Ar., and Triantafyllidis, V. (2009). Effects of irrigation system and green manure on yield and nicotine content of Virginia (flue-cured) Organic tobacco (Nicotiana tabacum), under Mediterranean conditions. Industrial Crops and Products, 29(2-3), 388 - 394

Burt, C. M., Clemmens, A. J., Strelkoff, T. S., Solomon, K. H., Bliesner, R. D., Hardy, L. A., Howell, T. A., and Eisenhauer, D. E. (1997)." Irrigation Performance Measures: Efficiency and Uniformity". Journal of Irrigation and Drainage Engineering, 123, 423442 https://doi.org/10.1061/(ASCE)0733-9437(1997)123:6(423)

Cottenie, A., Verloo, M., Kickens, L., Velghe, G. and Camerlynck, R. (1982). Chemical analysis of plants and soils. Laboratory of Analytical and Agrochemistry. State University, Ghent Belgium, PP. 100 - 129.

El-Hendawy, S.E., El-Lattief, E.A.A., Ahmed, M.S., and Schmidhalter, U. (2008). Irrigation rate and plant density effects on yield and water use efficiency of dripirrigated corn. Agric. Water Manage. 95 (7) 836-844. 
El-Noemani, A.A., Aboamera, M.A.H., Aboellil A.A.A., and Dewedar, O.M. (2009). Growth, yield, quality and water use efficiency of pea (Pisum sativum L.) plants as affected by evapotranspiration (Eto) and sprinkler height. Minufiya J. Agric. Res., 34(4), 1445-1466.

El-Noemani, A. A., Aboellil, A. A.A., and Dewedar, O.M. (2015). Influence of irrigation systems and water treatments on growth, yield, quality, and water use efficiency of bean (Phaseolus vulgaris L.) plants. International Journal of Chem Tech Research. Vol.8, No.12 pp 248-258.

El-Noemani, A. A., El-Zeiny, H.A., El-Gindy, A. M., El-Sahhar, E. A., and ElShawadfy, M. A. (2010). Performance of Some Bean (Phaseolus Vulgaris L.) Varieties under Different Irrigation Systems and Regimes. Australian Journal of Basic and Applied Sciences, 4(12), 6185-6196.

El-Seifi, S. K., Hassan, S. M., Amer, A.H., and Khairy, E.M. (2014). Effect of plant population and sowing dated on growth and yield of dry bean (Phaseolus vulgaris,L), plant growth and yield. J. Plant Production, Mansoura Univ., Vol. 5 (7), 1143-1156.

Erdem, T., Erdem, Y.,Orta, H., and Okursoy, H. (2006). Water-yield relationships of potato under different irrigation methods and regimens. Scientia Agricola, 63(3), 226231.

FAO, FAOSTAT, (2019). Food and Agriculture Organization of the United, Rome, Italy. Ministry of Agriculture and Land Reclamation (EAS), Economic Affairs Sector. The Indicators Agriculture Statistics.

Haikel, M.A. and Farid, S.M. (2001). Effect of different irrigation systems on faba bean productivity in newly reclaimed soil. J. Agric. Sci. Mansoura Univ. Egy., 26, 34113418 .

Jacobs. H.S., Reed, R.M., Thien, S.J., and Withee, L.V. (1971). Soils laboratory exercise source book. Am. Soc of Agron. Mandison, Wisconsin.

James, L. G. (1988). Principles of farm irrigation system design. New York: John Wiley and Sons. Pp. 545

Kassab, O.M., El-Noemani, A.A. and El-Zeiny, H.A. (2005). Influence of some irrigation systems and water regimes on growth and yield of sesame plants. J. of Agronomy, 4(3), 220-224.

Kassem, M.A., (2000). Comparative study for the effect of subsurface drip irrigation, surface drip irrigation and furrow irrigation systems on the growth and the yield of sunflower crop. Misr. J. Agric. Eng., 17 (2): 319-329.

Kazemi E., Naseri, R., Karimi, Z. and Emami, T. (2012). Variability of grain yield and yield components of white bean (Phaseolus vulgaris L.) cultivars as affected by different plant density in Western Iran. American Eurasian J. Agric. And Environ. Sci., 12 (1), 17-22.

Metin Sezen, S., Yazar, A., Canbolat, M., Eker, S., and Felike, G. (2005). Effect of drip irrigation management on yield and quality of field grown green beans. Agricultural Water Management, 71, 243-255.

Moniruzzaman, M., Halim, G. M. A., Firoz, Z. A. (2009). Performances of French bean as influenced by plant density and nitrogen application. Bangladesh J. Agril. Res. 34(1), 105-111. 
Narayanamoorthy, A., and Deshpande, R. S. (2003). "Irrigation development and agricultural wages: An analysis across states", Economic and Political Weekly. 38,3716-3722.

Nassar H.H., (1986). The relationship between yield and growth characteristics in some snap bean varieties. Annals Agric. Sci., Fac. Agric., Ain Shams Univ., Cairo, Egypt. 31(2), 1351-1366.

Nielsen, D. C. (2018). Dry bean water use/yield production function to estimate dryland yields in the U.S. Central High Plains. Field Crops Research, 228(September), 60-67.

Pawar, S.U., Kharwade, M. L., and Awari, H. W. (2007). Effect of plant density on vegetative growth and yield performance of different varieties of French bean under irrigated condition. Karnataka J. Agric. Sci., 20 (3), 684-685.

Phene, C.J. (1991). Irrigation research initiatives in California. Proc. Southern African Irrigation Symposium, 4-6 June, pp: 34-41.

Rafie, R.M., and El-Boraie, F.M. (2017). Effect of Drip Irrigation System on Moisture and Salt Distribution Patterns under North Sinai Conditions. Egypt. J. Soil Sci., 57(3),247-260.

Ramana Rao, K.V., Gangwar, S., Bajpai, A., Keshri, R., Chourasia., L., and Soni, K. (2017). Performance of pea under different irrigation systems. Legume Research, 40 (3), 559-561.

Raza, A., Zaka, M. A., Khurshid, T., Nawaz, M. A., Ahmed, W., and Afzal, M. B. S. (2020). Different irrigation systems affect the yield and water use efficiency of Kinnow Mandarin (citrus reticulata Blanco.). The Journal of Animal \& Plant Sciences, 30(5): 2020, Page, 1178-1186.

Scholberg, J. M. S., and Locascio, S. J. (1999). Growth response of snap bean and tomato as affected by salinity and irrigation method. HortScience, 34(2), 259-264.

Tomar, A. S., Chauban, H. S., and Singh, K. K. (1999). Influence of drip and other methods of irrigation on reproductive growth components and shoot-root characteristics of French bean. Journal of Agricultural Engineering. Vol. 36(4), 43-48.

Unlu, M., Kanber, R., Senyigit, U., Onaran, H., and Diker, K. (2006). Trickle and sprinkler irrigation of potato (Solanum tuberosum L.) in Middle Anatolian Regionin Turkey. Agr. Water Mgt. 79,43-71.

Yin, X., Seavert, C.F., and le Roux, J. (2011). Responses of irrigation water use and productivity of sweet cherry to single-lateral drip irrigation and ground covers. Soil Sci. 176, 39-47.

Yonts, C. D. (2010). Deficit Irrigation of Dry Edible Beans during Early, Mid and Late Season. In $5^{\text {th }}$ National Decennial Irrigation Conference Proceedings, 5-8 December 2010, Phoenix Convention Center, Phoenix, Arizona USA. St. Joseph, MI: ASABE. https://doi.org/https://doi.org/10.13031/2013.35866

Yonts, C. D., Haghverdi, A., Reichert, D. L., and Irmak, S. (2018). Deficit irrigation and surface residue cover effects on dry bean yield, in-season soil water content and irrigation water use efficiency in western Nebraska high plains. Agricultural Water Management, 199, 138-147. 
تأثيرنظام الري وتوزيع النباتات على النمو والمحصول وكفاءة استخدام المياه لبعض أصناف الفاصوليا

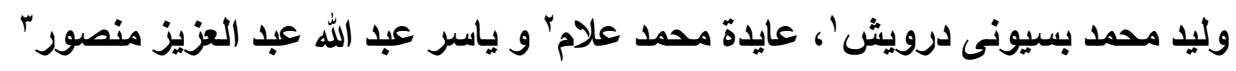

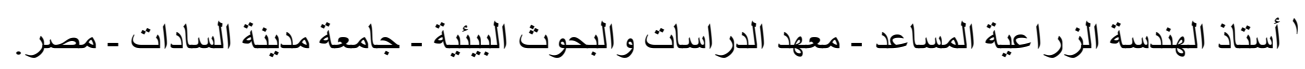

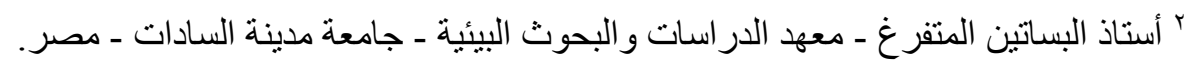

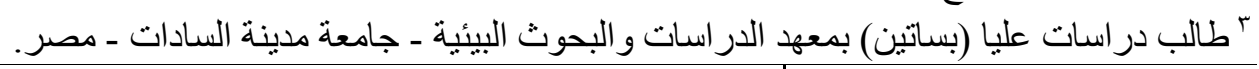

الملخص العربي

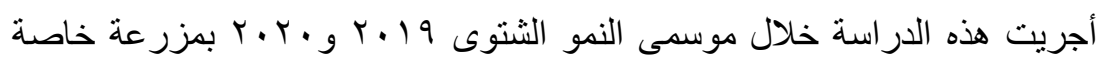
بمنطقة الخطاطبة منوفية بهدف معرفة تأثيرنظام الري وتوزيع النباتات على النمو

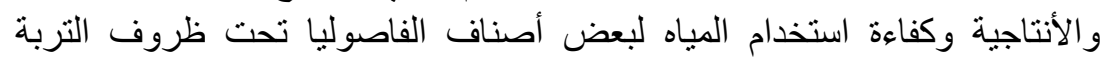

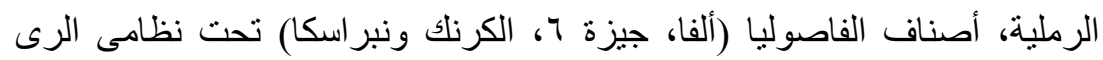

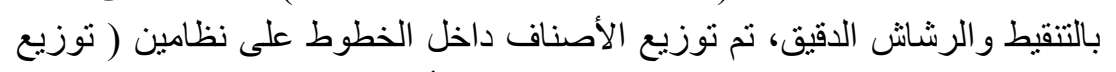

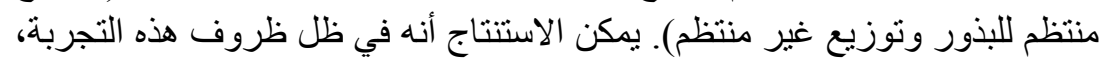

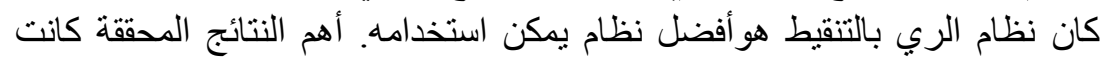
كالتالى: وجود فروق معنوية للتداخل بين نظام الرى، توزيع النباتات وأصناف الفاصوليا لكل

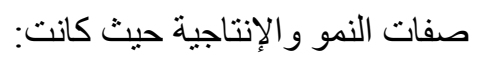

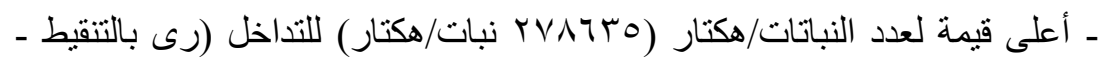
توزيع منتظم للنباتات - صنف ألفا) بينما أقل قيمة لعدد النباتات/هكتار (

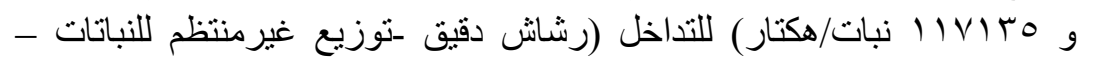

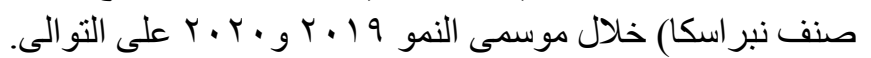

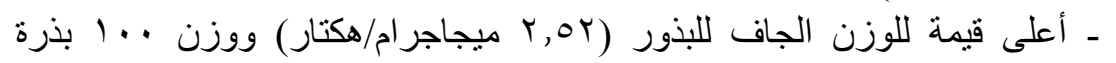

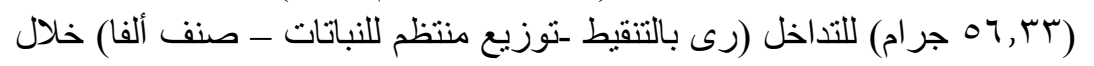

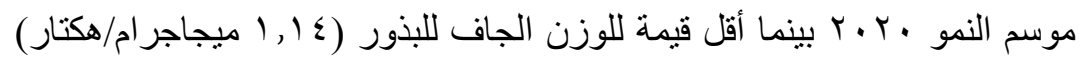

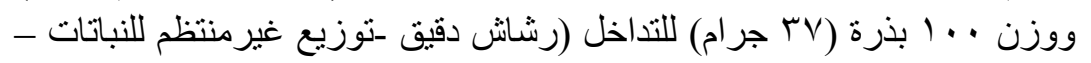

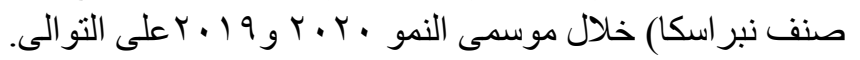

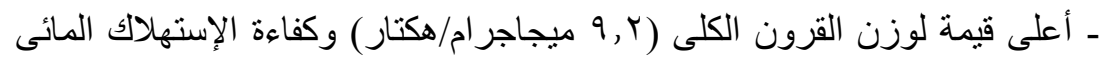

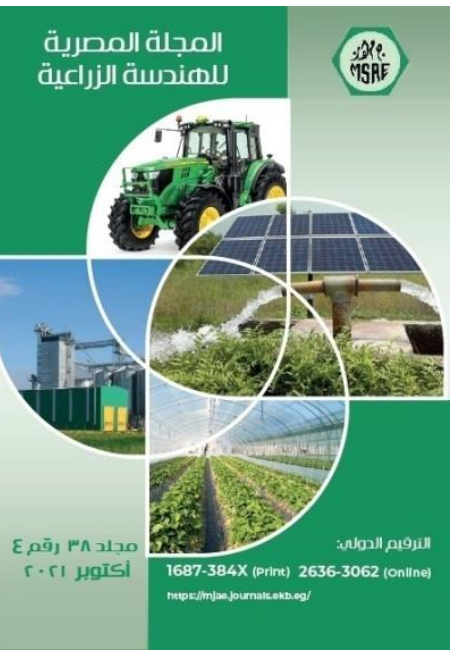

C المجلة المصرية للهندسة الزراعية

الكلمات المفتاحية:

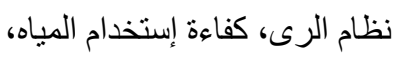
الفاصوليا، الإنتاجية

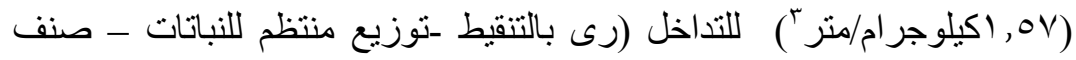

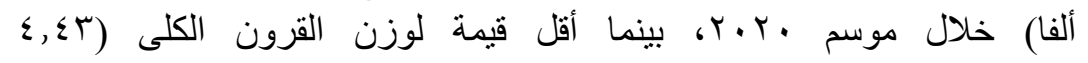

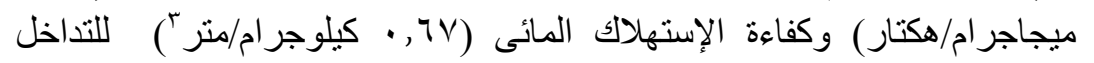

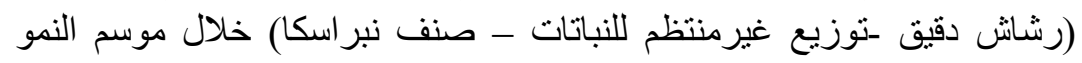

